\title{
Socialisation in Architectural Education: A View from East
}

\section{Africa}

Purpose - Concern for the state of architectural education in East Africa was a catalyst for this exploration of socialisation, which sought to understand socialisation and its influence on educational outcomes in the region. Socialisation within architectural education has long been known to influence how students acquire important aspects of the profession, building both values and a cultural ethos in the process. An appreciation of these processes in the context of East Africa adds to the wider understanding of the implicit curriculum in architectural education.

Design/methodology/approach - An ethnographic study was undertaken in five architecture schools across Kenya, Tanzania and Uganda, making use of a mixed method approach incorporating document analysis, a questionnaire study, participant observations and focus group discussions as the data gathering instruments. Focus group discussions, as the primary data gathering method, acknowledged the social context of the study, with data gathered from multiple sites across the region.

Findings - As an integral component of architectural education, socialisation was evident at all stages of the educational process. Within the educational realm, contrasting expectations of students and instructors were evident, leading to conflicts that influenced the values acquired by students. This was seen in attitudes toward contemporary architectural issues within architectural education, and suggests that socialisation can at times have pronounced negative consequences.

Originality/value - The wider study represents the first comprehensive review of architectural education in the context of East Africa, and contributes to the global appreciation of the influence of socialisation on educational outcomes.

Keywords - Architectural education, East Africa, Socialisation, Focus groups, Expectations 


\section{Socialisation in Architectural Education: A View from East Africa}

\section{Introduction}

Architectural education, which extends over several years, is fundamental to the transformation of students from novices to professionals. Aside from the acquisition of the explicit elements of architecture, students also acquire tacit elements of the profession, a consequence of the high level of interaction between instructors and students. It is through this interaction that students are initiated into the [cultural] norms of the architecture profession, making this socialisation process significantly influential in architectural educational. Interest in the transformation that occurs as part of architectural education, has formed the basis of several studies, including: Design Studio Pedagogy and Studio Culture (Dutton, 1987; Anthony, 1991; Shannon, 1995; Wilson, 1996); Setting and Programme (Stevens, 1998); and, Context (Webster, 2008). This interest in the processes of architectural education, beyond its knowledge elements, showcases a growing awareness and importance of the tacit curriculum in professional education, and is an acknowledgement that education is a social process that does not occur in a vacuum (Bragg, 1976; Fung, 1996). However, as these social processes are difficult to quantify, and thus largely undocumented, they are often taken for granted (Stevens, 1998). I thus ponder the question: 'What therefore are the effects of the socialisation process?' This question was investigated in the context of architecture education in East Africa (incorporating Kenya, Tanzania and Uganda), seeking to understand factors that affect and influence learning within architecture schools in the region.

Understanding socialisation could serve as a means to unpack the closed nature of architectural education, which is so intertwined with its socio-cultural processes, it has been described it as ' $a$ black box', leading Banham to quip, "Anthropologists have already gone a long way in penetrating the inner workings of societies far more remote than the tribe of architecture" (Banham, 1996, p. 299). This view of the closed nature of architectural education, evokes notions of sameness, or cults, as pointed out by Till, citing Jacques Lucan, in reference to Miroslav Sik's Atelier at the ETH Zurich, “... whose members' 'black uniforms and deliberate 
isolation bore overtones of a clan'..." (Till, 2005, p. 1). More extreme are notions of indoctrination, as presented by Bobel (2006), or [cultural] cloning, described by Essed and Goldberg, as the "... systematic reproduction of sameness" (2002, p. 1067). No doubt at the extreme, socialisation can be dangerous, creating sub cultures and social injustices that could have a negative impact on students. In some contexts, as in East Africa, the notion of sameness is actively promoted under the guise that this is desired by society; more so in the context of professional education, where it is often asserted that sameness is what the public desires.

A review of architectural curricula across East Africa revealed that tacit elements were largely absent in formal documentation, although the outcomes of the interaction being students and instructors was overtly evident, seen in the transformation of students over the course of their education, but not necessarily tied to the mastery of espoused knowledge. Two elements evident in architectural education thus emerge: professionalisation: which is the 'learning' of explicit aspects of a curriculum (such as knowledge, and skills) (Bess, 1978, p. 292), as well as socialisation: described as the acquisition of the tacit aspects of a profession (Bragg, 1976, p. 6). This duality suggests that some aspects of the curriculum can be 'taught', but others are 'caught' (Kibor et al., 2010), exemplified by the educational experience of art educator Odoch Pido (2002) whose schooling cast him as tabula rasa; a clean slate onto which new knowledge could easily be written and effected as " $[\ldots]$ the transmission of packaged, or pre-digested, information - education as instruction administered to the 'ignorant' by experts [...]" (Mills and Lipman, 1994, p. 215). This view of education, prevalent across East Africa, is reinforced by the honour attached to genealogical seniority among other 'traditional' values, as highlighted by Foster (1961), and Hobsbawm and Ranger (1992). A power relationship, particularly overt in architectural education was evident, a consequence of the close relationship between instructors and students, invariably impacting on learning, as highlighted by Dutton (1987):

... while architecture is intimately related to societal relations of power, it is important to judge what effect this relationship has on the education of future architects. .... Thus, what is taught in design studios plays a strategic role in the political socialisation of students (Dutton, 1987, p. 17). 
Equally important are the students themselves, whose long hours of association within the educational setting, contributes to the building of sub-cultures (Anthony, 1991), an aspect of socialisation not generally acknowledged in the literature, although a related area - peer learning - is often presented as an important element in education (Chamberlin, 2010; McClean et al. 2013). Further, a general assumption within education has been that it is a one-way process from instructor to student - but not between students, and certainly not from student to instructor. In the context of East Africa, where a paternalistic approach to education is dominant, acknowledgement of student and peer influence has only emerged in relation to cheating, a negative aspect of this interaction that ensured instructors dissuade any collaboration amongst students (Basaza, 2006).

\section{Socialisation in architectural education}

For the purpose of this paper, socialisation is defined as “... that process by which individuals acquire the values, attitudes, norms, knowledge, and skills needed to perform their roles acceptably in the group or groups in which they are, or seek to be, members" (Bragg, 1976, p. 6). With architectural education having a relatively loosely defined pedagogy based around the design studio, socialisation emerges as particularly influential in the transformation of individuals as they progress through architecture school. While knowledge is a key part of education, it is also acknowledged that architectural education is where “ ... students gradually take on language codes, stylistic preferences, and rituals of architects, while becoming increasingly remote from the way laypeople describe and prioritise architecture" (Strickfaden and Heylighen, 2010, p. 122). This effectively presents architectural education as being akin to indoctrination, with novices assimilated into the language, the dress, and way of thinking of architecture (Coleman, 2010), equipping individuals with essential professional intricacies not normally included or evident in the main curriculum, but “... slowly absorbed from those who are already cultivated" (Stevens, 1998, p. 196). In this case, instructors who are already encultured into architecture through their own education (and practice), emerge as key patrons of educational socialisation, and who set the framework within which socialisation takes place 
(Bess, 1978; Strickfaden and Heylighen, 2010). It is this influence on students within architectural education that makes socialisation an important area for investigation.

\section{Methodology}

The study was undertaken over a three-year period, in five schools of architecture across East Africa; two schools offered dual degree programmes, while the other three had traditional 5year single degree programmes. The student intake varied from 25 in one of the newer schools, to over 150 in one of the older established universities. As an ethnographic study seeking to garner information on socialisation, an approach that allowed participants to engage directly with the key issues was necessary. This was provided through a mixed methods approach, with emphasis on focus group discussions; an economical, fast and efficient method to obtain data from multiple participants. Focus group discussions are generally carried out in a socially oriented environment, giving participants a sense of belonging, while creating opportunities for unexpected but valuable responses (Onwuegbuzie et al., 2009). Other methods of data collection employed included: a questionnaire study of practicing architects and architectural educators, which was used to consolidate ideas garnered from the literature, as well as participant observations in selected schools; together these provided rich information from diverse viewpoints. As the primary data collection method, focus groups were useful in engaging discussants in conversation and debate, while also enabling participants to venture into topics deemed important within the framework of the discussions. In the context of East Africa, focus groups also served to circumvent a key challenge faced in social research; a lack of confidence in the 'system', with participants often hesitant to divulge information fearing it may be used against them. By allowing disagreements, debate and corrections among discussants, focus groups enable instant validation of information through oral engagement, something not possible through questionnaire based studies. Finally, to ensure key topics were covered and discussions progressed steadily within agreed time limits, key themes were introduced during the conversations as and when necessary.

In all, 71 self-selected discussants participated in ten focus group sessions. Separate sessions were conducted for students and instructors to provide settings conducive to peer conversation. 
With diverse participants, the sequence in which topics were discussed varied widely, upholding a key strength of focus group discussions; their open and relaxed nature (Onwuegbuzie et al., 2009). More than 15 hours of discussions were recorded, made using dual hardware and software systems: Sound Studio ${ }^{\mathrm{TM}}$, and Voice $\mathrm{Memos}^{\mathrm{TM}}$ in order to minimise misinterpretation and error. Analysis of transcribed data was through Template Analysis to thematically categorise and analyse the qualitative data, identifying overt or itinerant patterns within discussions (Crabtree and Miller, 1992). Analysis initially made use of a priori codes derived from the literature and the questionnaire study to describe and code the data (see Table 1).

A key benefit of template analysis is the ability to incorporate additional themes as data is mined for patterns and ideas, accommodating new themes and categories that arise. The final template thus incorporated 43 subcategories divided into six main groups as presented in Table 2. This was a significant increase on the initial 15 a priori codes, and an indication of the myriad of issues deliberated upon in the various focus groups. The findings presented in this paper relate to educational socialisation, specifically the category, 'building professionals', which presented aspects of socialisation related to the design studio, as well as engagement with contemporary issues in architectural practice and education.

\section{Teaching, learning and the [D]esign studio}

As a key part of architectural education, the design studio is not only a place for architectural design exploration, but also where there is significant interaction between instructors and students, as well as amongst students. The one-on-one interaction between instructors and students is intrinsically linked to the instructors' background, and their familiarity (or otherwise) of architectural pedagogy and the broader goals of architectural education. The study revealed that many faculty had limited awareness of contemporary educational pedagogy, generally peddling what had been garnered through their own education and experiences as students, a phenomenon described as 'yellow notes', in reference to the deterioration of paper as it aged over time (Olweny, 2013). In addition, the privileged position of instructors was also significant, as highlighted by Foster (1961) and Pido (2002), and largely related to seniority often utilised to inculcate ideas in students. 
Within the studio, instructor-student relations were generally strained, linked to an education structure that did not encourage inquisitiveness, exploration or the development of independent positions, but rather obliged students to accept what was taught without question. This was poignantly illustrated by one student: "[...] we had a lecturer, ok an ex soldier, or something $[\ldots]$ sincerely, this is a guy who, ... it was like you were competing with him $[\ldots]$ of course, you don't know, he knows. He is the instructor, and they're pumping their own ideas into your head $[\ldots] "\left(F G 4 \_3\right)$. Such sentiments were certainly not isolated, and evident across the region, with another student stating: “[...] in School A it's still the same old traditional kind of institution like arrangement, where there are gods, and servants; subjects, and slaves; you know, masters and slaves. [...]" (FG3_2). The idea that instructor-student interactions were likened to a 'master-slave' engagement highlights a skewed power relationship within the studio, in which instructors in a position of authority could inculcate their views and values onto students, often with little contention. Students often risked failure if they did not conform to these espoused views, as described by one student: "It has been trying for us, students trying to defend their ideas. But at the end of it all, you want the marks [Laughter] and it's the tutor who has the marks" (FG2-2). This overt teacher-centred approach effectively negated a key aspect of contemporary architectural education, its collegiality and collaboration, instead emphasising a 'do as I say, and not as I do' approach, reducing opportunities for students to develop independent thought through their engagement with studio projects, thus promoting conformity and subservience, rather than enabling "mastery of the mystery" (Argyris and Schön, 1974, p. $185)$.

Linked to interactions between instructors and students, was availability of faculty for formative assessment sessions, emerging as a key concern for both students and instructors (See Table 3). It was discovered that availability of faculty within the studio was often limited although not a direct consequence of large student numbers. In most schools, full-time instructors were also engaged in full-time practice; while engaging in architecture practice in itself is essential for professional development of academic faculty, in East Africa the difference in remuneration between academia and in practice, which effectively led academics to become practitioners first and academics second. This served to restrict availability of faculty outside formal sessions, 
with attendance during timetabled sessions also somewhat erratic. At a broader level, this served to skew instruction toward current practice, more often than not based on tried and tested approaches, with students actively dissuaded from going beyond those solutions. This is exemplified by the following two quotes uttered by practicing architects: "Architects don't design bridges!" (2008), and "I don't remember ever being taught to be in-charge of health and safety on site in all my architecture courses" (2011). Such statements suggest static engagement with issues within the constantly evolving landscape of architectural discourse and practice (Olweny, 2015).

The limited availability of instructors during studio sessions led students to seek out alternative ways to gain feedback, with student peers emerging as the major avenue for this. However, while students did engage with their peers as part of design explorations, they were often reluctant to fully share details of projects, fearing their ideas would be stolen, a result of stiff competition among them: “[...] and maybe the reason why it's, it doesn't work for most students cause we have competition amongst us.” (FG8_10). This reflects inherent views of learning garnered during pre-university education; perceived as an individual activity, based around the assimilation of proprietary knowledge, engaging in what has been described by Argyris and Schön (1974, p. 82) as attribution (the unilateral assignment of intentions without public testing), and social evaluation (directly comparing and competing with each other). Negative attitudes toward sharing of information extended to perceptions of teamwork and working in groups, reinforced by summative assessment regimes that privileged individual activities over group tasks. This gave students little incentive to participate in teamwork exercises or to work in groups, as expressed by focus group discussants (See Table 4).

Negative attitudes toward teamwork, and working in groups, were heightened by strongly held views of architecture being about individual creativity, and expressed through solo design projects. This in itself was founded on long standing myths surrounding architecture and the architect, perceived as the 'Master-builder' and in the context of contemporary architectural practice interpreted as the 'Solo Virtuoso Designer' (Weisman, 1996), or the 'Lone Ranger Master Architect' (Briggs, 1996). Working in groups was therefore viewed as stifling to 
individual creativity, and merely a means for instructors to reduce their workload, rather than as an important component of architecture educational pedagogy. This aversion toward teamwork and working in groups creates a dilemma for architectural education, diminishing the development of 'reflect-in-action' and 'reflect-on-action' as presented by Schön (1988), which according to Bruffee (1995) are generally learned as a result of interactions with others. Paradoxically, the limited interaction between instructors and students, as well as the constrained relationship amongst students themselves formed a major factor in the development of students, more so in relation to contemporary issues as part of architectural education.

\section{Contemporary issues in architectural education.}

Two areas were particularly significant with regard to engagement with contemporary issues in architectural education: Environmental Sustainable Design (ESD), and the use of computers in architectural education. The study revealed a general lack of engagement with these contemporary issues within architectural education, effectively relegated to the periphery of programmes, as noted by one faculty member with regard to ESD: "ZERO! Ok, Zero in the sense that, even when I want, ok, even when the students want, sometimes the academic, fellow academic staff can be the obstacle, ok. [...] these people are not interested in sustainable building design" (FG10_4). Engagement with ESD was often discouraged as a consequence of this being a relatively new concern in architectural education, and therefore had not been a part of the instructors' own education, not to mention limited engagement with ESD in the professional realm. The limited engagement was often blamed on a lack of local precedents, linked to planning and building regulations, which for many municipalities had remained unchanged since the 1950s, and enforced with little regard for technological developments (Olweny and Olweny, 2010). Planning and building legislation was thus retrogressive, dissuading the implementation of innovative solutions, which translated to students being hesitant to engage with ESD as part of their design solutions as this was not the 'norm' in the professional realm: “[...] when you talk about green materials, green way of doing things, you know there is also the risk of, will my plans be approved, or will the client welcome these ideas [...].” (FG1-2). Nevertheless, while faculty were not particularly enthusiastic about including 
ESD as part of the design exploration, a number of students did have opposing views, acknowledging that ESD was a pressing issue in contemporary architecture, and were thus interested in gaining a better understanding of the subject. The absence of ESD in many curricula therefore left students disappointed, more so as this absence was perceived as a regressive approach to architecture (See Table 5).

Unlike ESD, which espoused ideals of future practice, engagement with computers was largely about the existing state of architectural practice, but found to be used only for word processing, $3 \mathrm{D}$ rendering, and 2D drafting; for the latter two, mainly in the senior years of the programmes. On the whole instructors discouraged the use of computers, with only two schools engaging students in computer based building performance analysis, albeit at a rudimentary level. None of the schools included computer based BIM tools as part of design studio teaching. Pedagogical arguments were often presented as justification for not incorporating computers into the educational process, citing the ease with which it enabled copying: "Well, my finding is students love to produce materials by computers because it enables them to forge, so [laughter] (FG10_3 - yes: FG10_2 - plagiarise, plagiarism; FG10_3 - copy-paste, copy-paste ...). That's it, so in this case, in my classes I discourage completely the use of computers [...]" (FG10_4). Such sentiments reflect those highlighted earlier by Basaza (2006) with relation to educational pedagogy.

The lack of computers in architectural education could be viewed as a consequence of many instructors having had limited exposure to computers as part of their own education, and thus unable to engage students in the use of computers as part of the design process (See Table 6). This lack of computing as part of the architectural curriculum seems to persist, although it had been highlighted in the past, with Okany-Dimoriaku (2004) revealing that of twenty instructors in one architecture school in Nigeria, only one knew how to use AutoCAD - the CAD package used in that school. Ironically the prevalence of computers in practice, albeit largely for drafting and rendering added to this contentious debate, with students at a loss to explain why they were not being taught $\mathrm{CAD}$, yet this was exactly what they believed practice expected them to know. This presented a source of conflict between instructors and students, which along with 
ESD exposed negative elements of socialisation within the educational realm; serving to reinforce a growing view that architectural education is not preparing students for [current] practice.

Rejection of contemporary issues, simply because they were not part of the instructor's prior education, highlights the strong influence of tradition within architectural education, with students socialised into pre-established 'norms', and in so doing failing to acknowledge changes within society and the architecture profession. Socialisation can thus be seen as an important element in the moulding of students; nevertheless, the contentions presented here in relation to ESD and CAD suggest that the tacit curriculum embedded within architectural education (either intentionally or unintentionally), although believed to be beneficial, may at times prove corrosive in the development of future professionals.

\section{Discussion and educational implications}

Contemplating some of the outcomes of socialisation in the context of contemporary architectural education in East Africa, it is necessary to reflect on the historic origins of formal education in the region. Initially this was geared toward the acquisition of 'new' and 'useful' knowledge, to enable participation in the introduced societal structures of the early colonial era, with instruction provided by religious missionaries, traders, and to a lesser extent the colonial administration and the military (Beck, 1966; Kithinji, 2012; Parsons, 2000). Within this system, education was framed as the “... transmission of packaged, or pre-digested, information education as instruction administered to the 'ignorant' by experts ..." (Mills and Lipman, 1994, p. 215), and geared to meet the needs of a 'modern' parallel co-existing society. Inheriting this systems, post-colonial governments found this as a useful tool to advance their ideological agenda (Kithinji, 2012); the emphasis on knowledge as the basis of education having been founded on a belief that " [...] knowledge in its pure form [was] considered apolitical and universally relevant [...]" (Owolabi, 2007, p. 71), thus knowledge itself was eminently valued. Education as a consequence was framed as 'studying about' rather than 'participating in' educational activities, effectively leading to the commodification of knowledge. Within such an environment, students are little more than passive receivers of knowledge, provided by 
instructors who not only controlled this proprietary knowledge, but also its dissemination, and in some cases its application as well.

For architectural education in East Africa, initially started to train technicians to work as assistants to fully qualified Royal Institute of British Architects (RIBA) graduates, emphasis on the transfer of 'useful' knowledge was paramount, largely as much of what was being taught was either being seen by students for the first time, or only seen in text books. Architecture education was therefore established as 'studying about' new building technologies outside the realms of everyday livelihoods. In this context, academic faculty as custodians of architectural cultural capital could easily pass on their particular 'brand' of architecture, not necessarily because it is a better option or approach, but solely as they are the more influential proponent (Dutton, 1987; Webster, 2008). Consequences of this approach are evident in changes in students over the course of their studies; their initial enthusiasm gradually replaced with conformity - giving instructors 'what they want' - in order to smoothen the journey through the educational process. This could be regarded as 'Enforced Socialisation', where individuals on the receiving end, have little or no control of their socialisation experience (Olweny, 2015). The outcomes of the socialisation process as presented here, showcase recurring themes in architectural education across the globe. The endurance of the status-quo approach to teaching does have implications to the way students and practitioners engage not only with architecture as a discipline, but also with emerging issues. This is exhibited in the two statements: “Architects don’t design bridges!" and, "I don't remember ever being taught to be in-charge of health and safety on site in all my architecture courses" as presented earlier. Such utterances suggest that socialisation does have consequences that linger well into the professional realm. Paradoxically, while students entering architecture school do generally have the potential to become 'good' architects, the opportunity to grow as architects is encouraged (or impeded) by the socialisation process. This raises questions about the purpose of architectural education; is it to educate for the 'unknown future', or is it geared to perpetuate a 'known past'? With students in East Africa often coming into architectural education expecting to be taught [all] the virtues of the profession, and what it takes to make them experts (Olweny and Nshemereirwe, 2006), it 
is becomes apparent how the socialisation process could easily encourage acceptance of a particular point of view.

With the interaction between faculty and students described as akin to a 'master-slave' relationship, a situation that does not augur with the building of reflective practice and collegiality has been created. It also does not encourage questioning of, nor enable the (re)construction of architectural discourse (Webster, 2007), with far reaching consequences to the growth of architecture as a profession. The underlying currents within this state of play do indicate a potential shift in how cohorts of students respond to the perceived widening chasm between their own values, and those espoused through the established educational system. This may be significant in the formulation of subcultures within architecture, or even allowing a cultural inversion, defined by Ogbu as "[the] tendency for ... minorities to regard certain forms of behavior, events, symbols, and meanings as inappropriate for them ...” (Ogbu, 1992, p. 8), and as a consequence, seek out alternatives that better align with their values and beliefs. Such changes could be viewed as key to the establishment of what are regarded as alternative, or at the time of their founding, 'radical' pedagogical approaches to architectural education, geared to address perceived shortcomings in established perspectives. This route is not new, and was fundamental in the establishment of the Architectural Association in London in 1847, as well as numerous other 'alternative' schools over the years, such as: Southern California Institute of Architecture (SCI-Arc) - 1972, and more recently, the London School of Architecture - 2013. It remains to be seen how this plays out in the context of East Africa.

\section{Conclusion}

It is evident through this study that teaching is not value free, with knowledge and ideas constructed based on prior education, exposure, and experiences. Consequential outcomes of this status-quo approach are suggestions of a static and unchanging profession, giving a perception of the future as:

[...] a conservative extrapolation of the past. In this mindset, everything changes slowly, linearly, and predictably. This perspective encourages a strong adherence to inherited beliefs, methods, technologies, and social rules. Education means to reproduce the time 
honoured model of the world. Teaching is the handing down of existing knowledge to the next generation (Bermudez, 1999, p. 3).

In such a scenario, students are coerced into accepting existing conditions, supporting a key observation by Dutton (1987), who suggested that socialisation affects the growth of architecture discourse, and serves to reinforce and entrench the status quo. Socialisation also brings seniority and traditional teacher-centred approaches into the spotlight, as these give instructors significant authority and influence over students, creating asymmetrical power relationships within the educational realm, epitomised by the description of the relationship between faculty and students as one akin to 'gods' and 'servants'. This arguably makes socialisation more significant than explicit knowledge elements in the architectural curriculum. Crucially, the tacit elements of architectural education embedded within the socialisation processes could have lasting impacts on students and professionals, and therefore should be formally acknowledged, an appreciation of their value in the transformation of novices into architects. This would therefore be recognition that the implicit elements of the educational process are “... very powerful indeed even when [...] explicit knowledge is available by the bucketful" (Eraut, 2000, p. 122). While there has been a concentration on professionalisation, neglecting socialisation may present much more critical long-term implications. As such, understanding the underlying processes of socialisation would be an acknowledgement of this crucial role in the formulation of values in students, and its impact on the nature of architectural education and into architectural practice.

\section{References}

Anthony, K.H. (1991), Design Juries on Trial: The Renaissance of the Design Studio, Van Nostrand Reinhold, New York, NY.

Argyris, C. and Schön, D.A. (1974), Theory in Practice: Increasing Professional Effectiveness, Jossey-Bass, San Francisco, CA.

Banham, R. (1996), “A black box: The secret profession of architecture”. in Banham, M., Barker, P., Lyall, S. and Price, C. (Eds.) A Critic Writes: Selected Essays by Reyner Banham, University of California Press, Berkeley, CA., pp. 292-299.

Basaza, G.N. (2006), Distance Education and a Realistic Teacher Education Pedagogy in Uganda: Impact of an ICT-Supported Learning Environment, PhD Thesis, Ghent University, Ghent. 
Beck, A. (1966), "Colonial policy and education in British East Africa, 1900-1950", The Journal of British Studies, Vol. 5 No. 2, pp. 115-138. doi: http://dx.doi.org/10.1086/385522.

Bermudez, J. (1999), "The future of architecture education", in Legacy, proceedings of the 87th Association of Collegiate Schools of Architecture (ACSA) Annual Meeting in Minneapolis, MN, 1999, ACSA, Washington D.C., pp. 321-325.

Bess, J. (1978), “Anticipatory socialization of graduate students", Research in Higher Education, Vol. 8 No. 4, pp. 289-317. doi: 10.1007/BF00976801.

Bobel, C. (2006), “'Take this class if you like to be brainwashed': Walking the knife's edge between education and indoctrination", Human Architecture: Journal of the Sociology of SelfKnowledge, Vol. 4 No. 3, pp. 359-364, available at http://scholarworks.umb.edu/humanarchitecture/vol4/iss3/34 (accessed 17 August 2016).

Bragg, A.K. (1976), Socialization Process in Higher Education. ERIC/Higher Education Research Report No. 7., Publications Department, American Association for Higher Education, Washington, D.C., available at http://eric.ed.gov/?id=ED132909 (accessed 15 August 2016).

Briggs, D.C. (1996), "Opinion: Reform the design studio", Architecture, August, Vol. 88 No. 8 , p. 75 and 77.

Bruffee, K.A. (1995), "Peer tutoring and the "conversation of mankind"”, in Murphy, C. and Law, J. (Eds.), Landmark Essays on Writing Centers, Hermagoras Press, Davis, CA., pp. 87-98.

Chamberlin, J. L. (2010), The cultural reproduction of architecture: Examining the roles of cultural capital and organizational habitus in the socialization of architectural education. Thesis (Ph.D.), University of Michigan, Ann Arbor, MI., http://hdl.handle.net/2027.42/78907 (accessed 15 August 2016).

Coleman, N. (2010), "The limits of professional architecture education", Journal of Art and Design Education, Vol. 29 No. 2, pp. 200-212. doi: 10.1111/j.1476-8070.2010.01643.x.

Crabtree, B.F. and Miller, W.L. (1992), “A template approach to text analysis: Developing and using codebooks", in Crabtree, B.F. \& Miller, W.L. (Eds.) Doing Qualitative Research, SAGE Publications, Newbury Park, CA., pp. 93-109.

Dutton, T.A. (1987), "Design and studio pedagogy", Journal of Architectural Education, Vol. 41 No. 1, pp. 16-25. doi: 10.1080/10464883.1987.10758461.

Eraut, M. (2000), "Non-formal learning and tacit knowledge in professional work". British Journal of Educational Psychology, Vol. 70 No. 1, pp. 113-136. doi: 10.1348/000709900158001.

Essed, P. and Goldberg, D.T. (2002), "Cloning cultures: The social injustices of sameness", Ethics and Racial Studies, Vol. 25 No. 6, pp. 1066-1082. Doi: 10.1080/0141987022000009430.

Foster, P. (1961), White to Move? A portrait of East Africa today, Eyre and Spottiswoode, London.

Fung, S. (1996), "Notes on the architectural education of nomads", Architectural Research Quarterly, Vol. 2 No. 2, pp. 10-17. doi:10.1017/S1359135500001226.

Hobsbawm, E. and Ranger, T. (Eds.) (1992), The Invention of Tradition, Cambridge University Press, Cambridge.

Kibor, J., Okesson, G.A. and Okesson, K. (2010), “Shaping the 'hidden' curriculum for engaging power, poverty and wealth in Africa: A case study from Scott Theological College, 
Kenya", Third Lausanne Congress on World Evangelization, The Lausanne Movement, Cape Town, available at https://www lausanne.org/content/shaping-the-hidden-curriculum-forengaging-power-poverty-and-wealth-in-africa-a-case-study-from-scott-theological-collegekenya (accessed 15 August 2016).

Kithinji, M.M. (2012), “An imperial enterprise: The making and breaking of the University of East Africa, 1949-1969”, Canadian Journal of African Studies/ La Revue Canadienne des Études Africaines, Vol. 46 No. 2, pp. 195-214. doi: 10.1080/00083968.2012.702084.

McClean, D., Lamb, N. and Brown, A. (2013), "Marginal voices: Capitalising on difference in the design studio", Field, Vol. 5 No. 1, pp. 85-98, available at http://field-journal.org/wpcontent/uploads/2016/07/Field-51-McClean-Lamb-Brown.pdf (accessed 18 August 2016).

Mills, G. and Lipman, A. (1994), "Society and architectural education in South Africa - Are universities appropriate venues for schools of architecture?" Environment and Planning B: Planning and Design, Vol. 21 No. 2, pp. 213-221. doi: 10.1068/b210213.

Ogbu, J. U. (1992), “Understanding cultural diversity and learning”. Educational Researcher, Vol. 21 No. 8, pp. 4-14 and 24. doi: 10.3102/0013189X021008005.

Okany-Dimoriaku, I.D. (2004), Built heritage, computers and Nigerian design education. Thesis (Master of Advanced Studies in Architecture), University of British Columbia, Vancouver, available at http://hdl.handle.net/2429/15329 (accessed 15 August 2016).

Olweny, M.R.O. (2013), “(Re) Constructing architecture education in Uganda: Changing strategies and approaches in teaching and learning", in Hisarligil, B.B., Lokce, S. and Turan, O. (Eds.) Flexibility in Architecture Education, Chapter 5, Cambridge Scholars Publishing, Cambridge, pp. 62-76.

Olweny, M.R.O. (2015), Investigating the processes of socialisation in architectural education: Through experiences in East Africa. Thesis (Ph.D.), Cardiff University, Cardiff, available at http://orca.cf.ac.uk/77037/ (accessed 15 August 2016).

Olweny, M.R.O. and Nshemereirwe, C.V. (2006), "Educating built environment professionals: Perspectives from Uganda", paper presented at the 2nd Built Environment Education Annual Conference (BEECON), 12-13 September, London, UK.

Olweny, M.R.O. and Olweny, C.L.M. (2010), "Ethical Positions in Built Environment Education", in Bakker, K.A. (Ed.) The African City Centre: [Re] sourced, proceedings of the international conference in Pretoria, South Africa, 2009, University of Pretoria, pp. 173-177.

Onwuegbuzie, A.J., Dickinson, W.B., Leech, N.L. and Zoran, A.G. (2009), “A qualitative framework for collecting and analyzing data in focus group research", International Journal of Qualitative Methods, Vol. 8 No. 3, pp. 1-21. doi: 10.1177/160940690900800301.

Owolabi, K.A. (2007), "Knowledge production, cultural identity and globalization: African universities and the challenges of authenticity and transformation in the twenty-first century", in Kenny, J. (Ed.), The idea of an African university: The Nigerian experience. The Council for Research in Values and Philosophy, Washington D.C.

Parsons, T. (2000), "Dangerous education? The army as school in colonial East Africa", The Journal of Imperial and Commonwealth History, Vol. 28 No. 1, pp. 112-134. doi: 10.1080/03086530008583081.

Pido, J.P.O. (2002), "Mismatch in design education at the University of Nairobi", in Miettinen, S. (Ed.) Art - Design - Education - Exchange with Africa Seminar, Helsinki, Finland, 14-15 June, 2001, Department of Art Education, University of Art and Design, Helsinki, pp. 20-29, available at http://arted.uiah.fi/adeea/adeea1.pdf (accessed 15 August 2016). 
Schön, D. (1988), Educating the reflective practitioner, Jossey Bass, San Francisco, CA.

Shannon, S. (1995), The Studio Critique in Architectural Education. Thesis (PhD), University of Adelaide, Adelaide, available at http://hdl.handle.net/2440/18641 (accessed 15 August 2016).

Stevens, G. (1998), The Favored Circle: Social Foundations of Architectural Distinction, The MIT Press, Cambridge, MA.

Strickfaden, M. and Heylighen, A. (2010), "Cultural capital: A thesaurus for teaching design", Journal of Art and Design Education, Vol. 29 No. 2, pp. 121-133. doi: 10.1111/j.14768070.2010.01653.x.

Till, J. (2005), "Lost judgement", in: Harder, E. (Ed.) Writings in Architecture Education: EAAE Prize 2003-2005, European Association for Architectural Education (EAAE), Copenhagen, available at http://www.archdesign.vt.edu/news/pdf/eaae-prize-2003-05-essays.pdf (accessed 18 August 2016)

Webster, H. (2007), “The analytics of power", Journal of Architectural Education, Vol. 60 No. 3, pp. 21-27. doi: 10.1111/j.1531-314X.2007.00092.x.

Webster, H. (2008), “Architecture education after Schön: Cracks, blurs, boundaries and beyond", Journal for Education in the Built Environment, Vol. 3 No. 2, pp. 63-74. doi: 10.11120/jebe.2008.03020063.

Weisman, L.K. (1996), "Diversity by design: Feminist reflections on the future of architectural education and practice", in Agrest, D., Conway, P. and Weisman, L.K. (Eds.), The sex of architecture, Harry N. Abrams, New York, NY, pp. 273-286.

Wilson, M.A. (1996), “The socialization of architectural preference”, Journal of Environmental Psychology, Vol. 16 No. 1, pp. 33-44. doi: 10.1006/jevp.1996.0003. 